\title{
ANALYTICAL COMPARISON BETWEEN SPECTROPHOTOMETER AND PORTABLE GLUCOMETER FOR MEASUREMENT OF BLOOD GLUCOSE IN HORSE
}

Nanoshe Taye Jima

Addis Ababa University

Yoseph Cherinet Megerssa ( $\square$ yoseph.cherinet@aau.edu.et)

Addis Ababa University

Research note

Keywords: Glucometer, Glucose, Spectrophotometer

Posted Date: August 21st, 2019

DOl: https://doi.org/10.21203/rs.2.13351/v1

License: (c) (i) This work is licensed under a Creative Commons Attribution 4.0 International License.

Read Full License 


\section{Abstract}

Objective: Analytical methods comparison for the determination of blood glucose are essential in clinical laboratory practice as it improves the quality of health care through accurate and reliable clinical decision making. Therefore The study was done to assess the analytical performance between point-of-care glucometer and spectrophotometric methods for blood glucose determination. Results: Twenty paired samples from horses visiting SPANA clinic of college of veterinary medicine and agriculture Addis Ababa University was used. Data obtained from both instruments was compared. The results shows that the mean value of blood glucose concentrations were higher in by the glucometric method $(106 \mathrm{mg} / \mathrm{dl})$ than by the spectrophotometric $(73 \mathrm{mg} / \mathrm{dl})$ with the calculated t-statistic significantly different $p$-value of 0.000 . This study showed the clinical inaccuracy of the glucometer over the spectrophotometer.

\section{Text}

The authors have retracted the text of this preprint. 